\title{
DISASTER RISK MANAGEMENT: UPAYA PREVENTIF DALAM MEMBENTUK PERSEPSI MASYARAKAT MERESPON PANDEMI COVID-19
}

\section{DISASTER RISK MANAGEMENT: PREVENTION EFFORTS IN FORMING COMMUNITY PERCEPTION RESPONSE TO COVID-19 PANDEMIC}

\author{
Djoko Adi Prasetyo', Falih Suaedi ${ }^{2}$ \\ 1,2 Fakultas Ilmu Sosial dan Ilmu Politik Universitas Airlangga \\ e-mail: djokoadi.prasetyo@fisip.unair.ac.id
}

\begin{abstract}
The Covid-19 pandemic affects all sectors of life. The government has made various efforts to respond to the impact of the pandemic, but the success of government efforts is determined by public perceptions. Communities have an important role in shaping collective behavior in responding to pandemic disasters, there are people who respond well to pandemic disasters and there are people who underestimate pandemic disasters. The formation of public perceptions is caused by the lack of knowledge about the pandemic and the virus itself, so it is necessary to form public perceptions about the Covid-19 pandemic through disaster risk management. This community service activity aims to provide understanding and public awareness as a preventive effort in shaping the public's perception of responding to the Covid-19 pandemic. This community service activity is carried out by means of socialization and training to the community in Suko Sewu District, Bojonegoro Regency. The results of the pre-test and post-test on the practical knowledge of the community showed an average increase of 85 percent. With these results, it can help the public in forming perceptions about the Covid-19 pandemic and can transmit these perceptions to the surrounding community.
\end{abstract}

Keywords: Covid-19, Disaster Risk Management, Public Perception

\section{abstrak}

Pandemi Covid-19 berdampak pada semua sektor kehidupan. Pemerintah telah melakukan berbagai upaya dalam merespons dampak pandemi tersebut akan tetapi keberhasilan upaya pemerintah ditentukan oleh persepsi masyarakat. Masyarakat memiliki peran penting dalam membentuk perilaku kolektif dalam merespons bencana pandemi, terdapat masyarakat yang menyikapi bencana pandemi dengan baik dan terdapat masyarakat yang menganggap remeh bencana pandemi. Pembentukan persepsi masyarakat disebabkan oleh minimnya pengetahuan mengenai pandemi maupun virus itu sendiri sehingga perlu untuk membentuk persepsi masyarakat mengenai pandemi Covid-19 melalui disaster risk management. Kegiatan pengabdian masyarakat ini bertujuan untuk memberikan pemahaman dan kesadaran masyarakat sebagai upaya preventif dalam membentuk persepsi masyarakat merespons pandemi Covid-19. Kegiatan pengabdian masyarakat ini dilakukan dengan cara sosialisasi dan pelatihan kepada masyarakat di Kecamatan Suko Sewu Kabupaten Bojonegoro. Hasil pre-test dan post-test terhadap pengetahuan praktis masyarakat menunjukkan peningkatan rata-rata sebesar 85 persen. Dengan hasil ini dapat membantu masyarakat dalam membentuk persepsi mengenai pandemi Covid-19 dan dapat menularkan persepsi tersebut kepada masyarakat sekitar.

Kata Kunci: Covid-19, Disaster Risk Management, Persepsi Masyarakat

10.20473/jlm.v5i1.2021.123-129

Open acces under CC BY-SA license

$\underline{\text { Creative Commons Attribution-ShareAlike } 4.0 \text { International License }}$ 


\section{PENDAHULUAN}

Pandemi Covid-19 telah mengubah cara dan perilaku kita menjalani kehidupan seharihari, pandemi ini berdampak pada semua sektor. Sesuai dengan arahan pemerintah pusat bahwa pada kondisi pandemi Covid-19 diterapkan cara-cara baru yang masif yaitu pembatasan perilaku dan wilayah. Pembatasan perilaku diberlakukan saat suatu tindakan individu maupun kolektif yang berpotensi menimbulkan kerumunan dan perilaku masyarakat dituntut untuk menerapkan protokol kesehatan 3M (memakai masker, mencuci tangan, dan menjaga jarak). Pembatasan wilayah dilakukan dengan cara membatasi pergerakan masyarakat dalam skala wilayah. Selain itu berbagai pelayanan dan pekerjaan harus beradaptasi dengan cara-cara baru tersebut.

Pemerintah telah memberlakukan berbagai peraturan untuk merespons adanya pandemi Covid-19 diantaranya Peraturan Pemerintah Nomor 21 Tahun 2020 tentang Pembatasan Sosial Berskala Besar Dalam Rangka Percepatan Penanganan Corona Virus Disease 2019, Keputusan Presiden Nomor 11 Tahun 2020 tentang Penetapan Kedaruratan Kesehatan Masyarakat Corona Virus Disease 2019, Peraturan Menteri Kesehatan Republik Indonesia Nomor 9 Tahun 2020 tentang Pedoman Pembatasan Sosial Berskala Besar Dalam Rangka Percepatan Penanganan Corona Virus Disease 2019. Terakhir, melalui Keputusan Presiden Nomor 12 Tahun 2020 tentang Penetapan Bencana Non Alam Penyebaran Corona Virus Disease 2019 Sebagai Bencana Nasional. Keberhasilan upaya-upaya pemerintah dalam menghadapi pandemi Covid-19 tidak akan berhasil tanpa adanya kesadaran dari masyarakat (Buana, 2020).

Masyarakat memiliki peran penting dalam membentuk suatu perilaku kolektif dalam menghadapi bencana pandemi. Namun banyak masyarakat yang tidak menyikapi upayaupaya pencegahan penularan Covid-19 dengan baik, seperti pemerintah sudah meliburkan para siswa dan mahasiswa untuk tidak berkuliah atau bersekolah atau memberlakukan bekerja di rumah, tetapi kondisi ini dimanfaatkan oleh banyak masyarakat untuk berlibur (Malik, 2020). Indonesia sudah dalam keadaan darurat masih banyak dilaksanakan acara (seremonial) yang berpotensi membuat kerumunan (Hariyadi, 2020). Artinya masih banyak masyarakat yang menganggap ringan Covid-19. Selain itu juga masifnya pemberitaan mengenai pandemi Covid-19 memperburuk keadaan seperti protokol kesehatan pasien Covid-19 yang meninggal tidak bisa dilihat oleh keluarga (Mukarohmah, 2020). Implikasi dari kondisi tersebut adalah masyarakat enggan untuk memeriksakan kondisi apabila memiliki gejala atau melaporkan kepada pihak terkait apabila positif tertular Covid-19.

Pembentukan persepsi masyarakat ini disebabkan oleh minimnya pengetahuan masyarakat mengenai pandemi maupun virus itu sendiri (Barak, 2006). Sehingga perlu untuk membentuk persepsi masyarakat mengenai pandemi Covid-19 dengan cara memahami risiko bencana, mempertimbangkan suatu bahaya, dan kerentanan terhadap bencana, konsep ini dikenal sebagai disaster risk management. Upaya ini bertujuan untuk membangun kesadaran, kewaspadaan, dan pengendalian diri masyarakat tentang pandemi Covid-19.

Provinsi Jawa Timur memiliki jumlah kasus Covid-19 salah satu tertinggi di Indonesia. Secara umum persebaran Covid-19 di Provinsi Jawa Timur belum bisa dikendalikan ditandai dengan kasus yang terus meningkat dari hari ke hari. Kecamatan Suko Sewu Kabupaten Bojonegoro memiliki pertumbuhan jumlah kasus yang datar. Hal ini dapat 
diasumsikan terdapat dua kemungkinan yang terjadi yaitu minimnya uji klinis yang dilakukan atau masyarakat enggan untuk melaporkan diri kepada pihak terkait.

\section{METODE PENGABDIAN MASYARAKAT}

Pengabdian masyarakat ini dilaksanakan berdasarkan analisis hasil penelitian dan diskusi dengan warga masyarakat yang tinggal di Desa Kalicilik Kecamatan Suko Sewu Kabupaten Bojonegoro Jawa Timur. Permasalahan yang terjadi yaitu ketakutan masyarakat yang disebabkan oleh minimnya pengetahuan masyarakat mengenai bagaimana cara menghadapi pandemi dan virus Cocid-19. Solusi yang ditawarkan melalui program pengabdian masyarakat dari Lembaga Penelitian dan Pengabdian Kepada Masyarakat (LPPM) dan Fakultas Ilmu Sosial dan Ilmu Politik Universitas Airlangga yaitu sosialisasi dan pelatihan tanggap bencana.

Kegiatan pengabdian masyarakat ini dilaksanakan dalam beberapa tahap yaitu persiapan, pelaksanaan, dan evaluasi. Pada tahap persiapan dilakukan dengan pembentukan panitia pelaksana kegiatan, pembuatan proposal, melakukan proses perizinan, observasi tentang kondisi kepekaan masyarakat mengenai isu Covid-19 di Kabupaten Bojonegoro (kondisi existiing), dan membuat undangan kegiatan kepada narasumber dan peserta.

Tahap pelaksanaan kegiatan dilakukan pada tanggal 7 Oktober 2020 dari pukul 09.00 14. 00 WIB, dengan rincian kegiatan yaitu melakukan sosialisasi mengenai pandemi dan Covid-19, melakukan sosialisasi manajemen bencana, dan melakukan pelatihan masyarakat mengenai sikap yang tepat apabila terkena Covid-19 atau apabila orang terdekat terkena Covid-19.

Tahap evaluasi dengan rincian kegiatan yaitu mereview hasil kegiatan melalui pre-test yang dilakukan sebelum kegiatan dan post-test yang dilakukan setelah kegiatan berlangsung terhadap masyarakat dan mengumpulkan masukan dari berbagai pihak. Evaluasi dilakukan untuk mengetahui respons peserta terhadap pelaksanaan kegiatan. Evaluasi dilakukan terhadap tingkat pemahaman dan partisipasi peserta.

\section{HASIL DAN PEMBAHASAN}

Pengabdian masyarakat untuk memberikan pemahaman mengenai disaster risk management sebagai upaya preventif dalam membentuk persepsi masyarakat merespons pandemi Covid-19 telah dilakukan oleh Tim Pengabdian Masyarakat dan mitra di Desa Kalicilik Kecamatan Suko Sewu Kabupaten Bojonegoro. Kegiatan diikuti oleh masyarakat Kecamatan Suko Sewu. Kegiatan ini dilakukan pada tanggal 7 Oktober 2020 berupa sosialisasi dan pelatihan. Narasumber kegiatan ini terdiri dari akademisi dari Universitas Airlangga dan praktisi dari Lembaga Pemberdayaan Masyarakat Kabupaten Bojonegoro.

Kegiatan sosialisasi dilakukan oleh pihak akademisi dengan menggunakan metode pemaparan secara visualisasi dengan menggunakan LCD. Terdapat dua kegiatan sosialisasi yaitu mengenai pandemi dan virus Covid-19 dan manajemen kebencanaan. Sebelum melakukan sosialisasi, dilakukan pre-test untuk mengetahui pemahaman dan kesadaran masyarakat Kecamatan Suko Sewu Kabupaten Bojonegoro mengenai disaster risk management. Penyuluhan ini dilakukan untuk mengatasi persepsi yang berkembang di masyarakat setempat mengenai pandemi Covid-19. 
Kegiatan pelatihan dilakukan oleh pihak praktisi dengan metode praktik secara langsung. Kegiatan pelatihan bertujuan untuk membentuk cara dan sikap yang tepat masyarakat apabila terkena Covid-19 atau apabila orang terdekat terkena Covid-19.

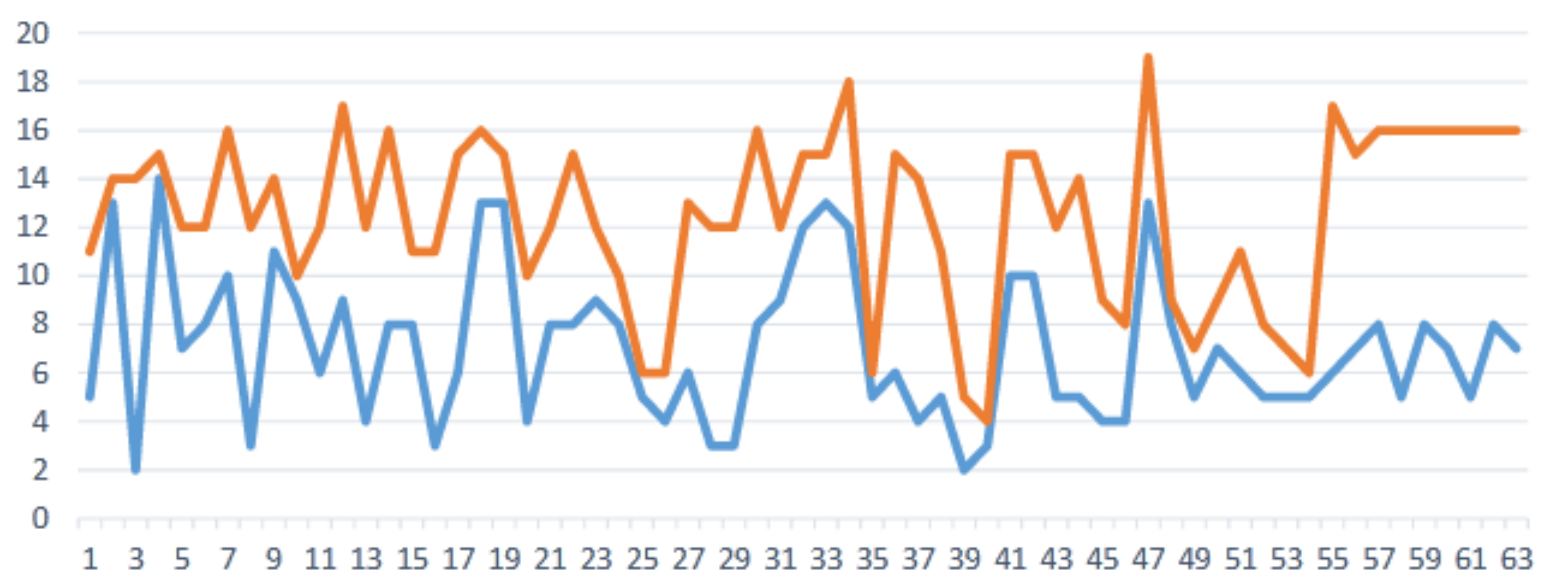

Tabel 1. Distribusi Peningkatan Pemahaman dan Kesadaran Masyarakat Mengenai Disaster Risk Management

Berdasarkan hasil evaluasi pres-test dan post-test yang telah dilakukan sebelum dan sesudah pelaksanaan sosialisasi dan pelatihan mendapati bahwa masyarakat di Kecamatan Suko Sewu Kabupaten Bojonegoro mengalami peningkatan kapasitas mengenai pemahaman dan kesadaran mengenai disaster risk management. Pemberian sosialisasi dan pelatihan dapat meningkatkan kapasitas masyarakat sehingga masyarakat mampu memahami dan menyerap serta memiliki pengetahuan terkait tanggap bencana dan kesiagaan menghadapi bencana. Hal ini dibuktikan dengan hasil nilai pre-test (sebelum kegiatan) lebih tinggi dibandingkan nilai post-test (sesudah kegiatan). Dari 30 orang masyarakat yang hadir, semuanya memiliki nilai yang menunjukkan peningkatan yang signifikan dengan rata-rata 85 persen. Hal ini mengindikasikan bahwa hasil dari kegiatan pengabdian masyarakat tentang disaster risk management di Kecamatan Suko Sewu Kabupaten Bojonegoro dapat dikatakan berhasil.

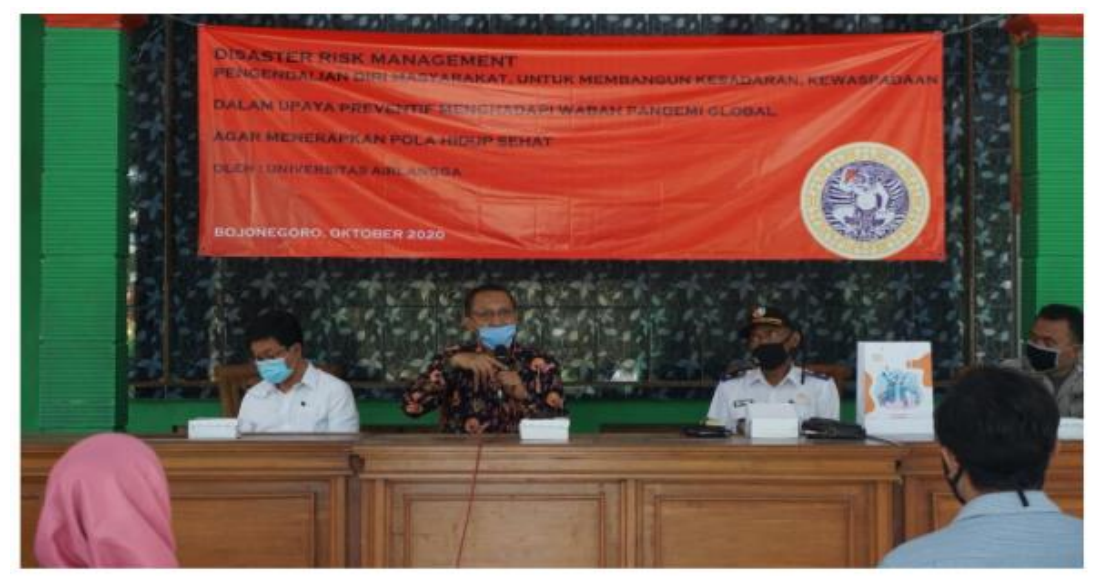

Gambar 1. Sosialisasi Mengenai Pemahaman Pandemi dan Virus Covid-19 


\section{Cara Penularan COVID-19}

COVID-19 DITULARKAN MELALUI

- DROPLET (percikan ketika orang batuk/berbicara) orang dengan COVID -19

\section{- Kontak erat}

seperti cium tangan, jabat tangan, berpelukan, cipika-cipiki.

- Menyentuh permukaan benda yang terkontaminasi virus Corona dapat bertahan pada permukaan benda mati selama berjam-jam sampai berhari-hari.

Gambar 2. Materi Sosialisasi Mengenai Pemahaman Pandemi dan Virus Covid-19

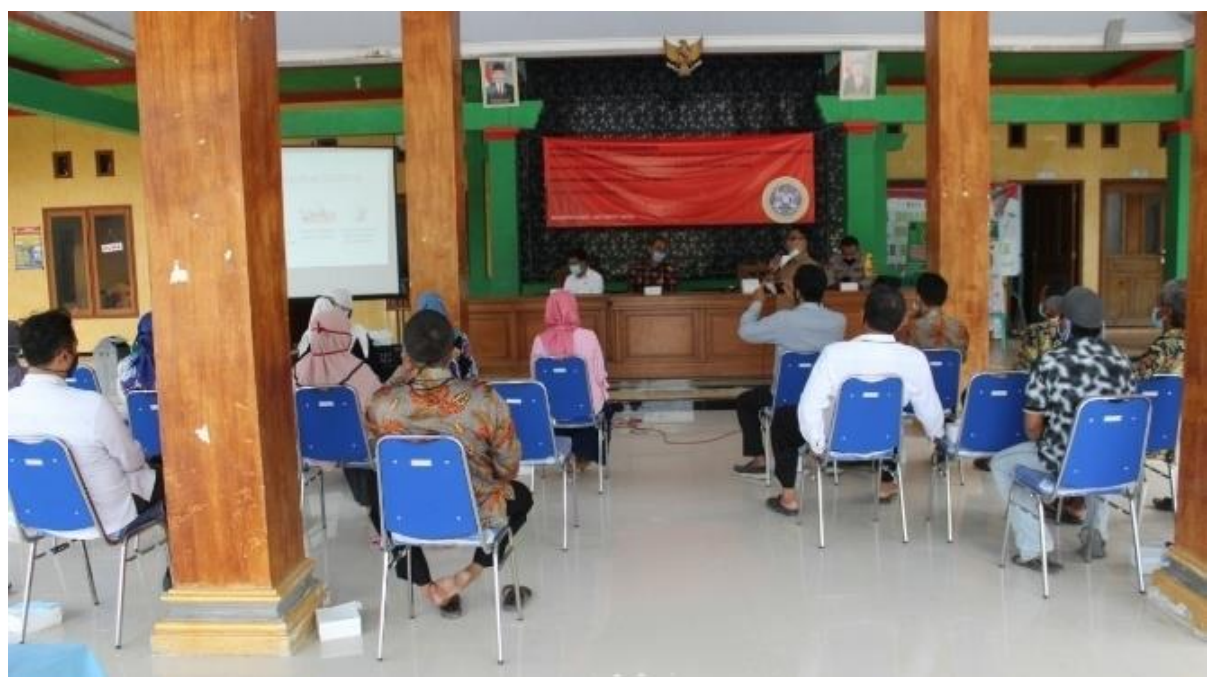

Gambar 3. Sosialisasi Mengenai Pemahaman Manajemen Bencana

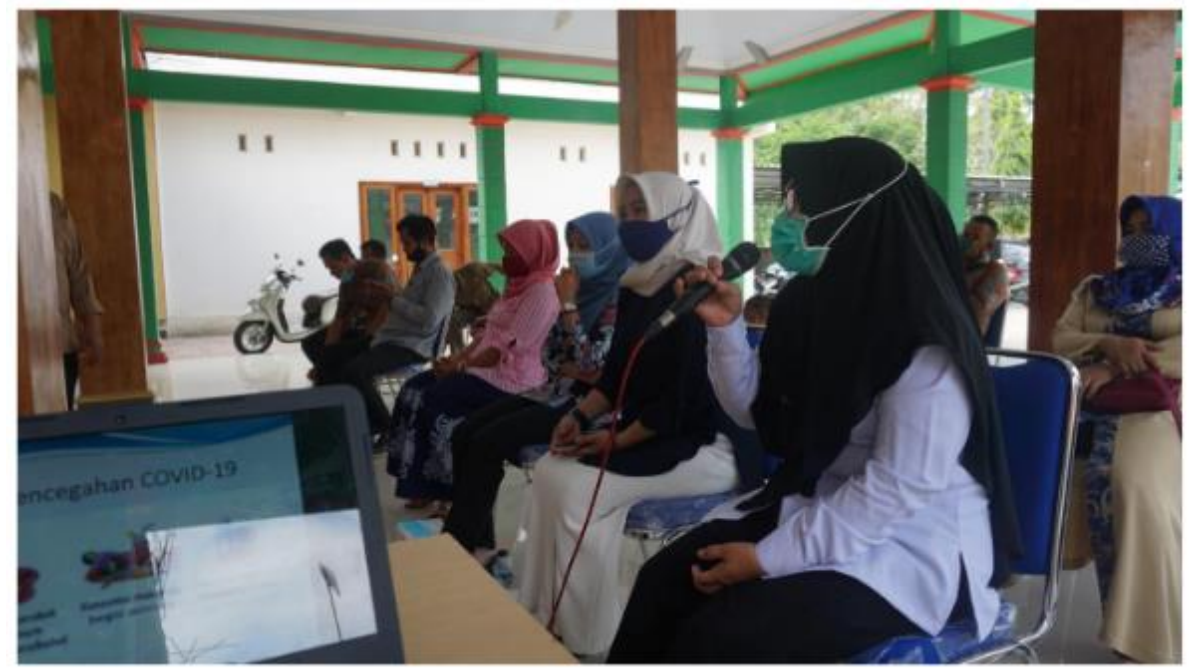

Gambar 4. Pelatihan Tanggap Bencana Pandemi Covid-19 
Pelaksanaan kegiatan pengabdian masyarakat di Kecamatan Suko Sewu Kabupaten Bojonegoro ini berjalan dengan baik dan lancar. Pengabdian ini ditujukan kepada masyarakat di Kecamatan Suko Sewu Kabupaten Bojonegoro dengan metode sosialisasi yaitu pemaparan materi yang dilakukan oleh para narasumber akademisi dan pelatihan yaitu praktik langsung tanggap bencana pandemi Covid-19 yang dilakukan oleh praktisi. Pengabdian masyarakat ini mampu meningkatkan pemahaman dan kesadaran masyarakat dalam manajemen bencana krisis saat ini.

Dalam proses sosialisasi berjalan seperti yang diharapkan yang dibuktikan dengan respons para masyarakat dalam menjawab pertanyaan yang diajukan dengan baik dan benar. Masyarakat juga memperhatikan proses pelatihan yang dilakukan oleh para praktisi pada kegiatan ini berjalan dengan baik. Dari pelatihan yang diberikan, masyarakat mampu mengetahui cara dan sikap yang tepat apabila terkena Covid-19 atau apabila orang terdekat terkena Covid-19.

Berdasarkan hasil evaluasi pelaksanaan kegiatan terdapat faktor pendukung dan penghambat dari kegiatan ini sehingga dapat berjalan dengan baik dan lancar. Faktor pendukung yaitu adanya dukungan dari berbagai pihak dari pemerintah desa, dinas kesehatan kabupaten, dan mitra praktisi yang ahli dalam bidang manajemen bencana. Sedangkan faktor penghambat yaitu kegiatan ini dilaksanakan dalam kondisi Pandemi Covid-19 sehingga adanya keterbatasan tempat dan peserta dalam kegiatan.

Berdasarkan hasil evaluasi pelaksanaan kegiatan terdapat beberapa masukkan dari kegiatan ini untuk berjalan dengan lebih baik kedepannya. Masukkan dapat diidentifikasikan berdasarkan masukkan teratas yang sering diberikan yaitu perlu diberlakukan kegiatan serupa agar masyarakat terutama yang ada di daerah pedesaan mendapatkan pengetahuan mengenai manajemen bencana saat pandemi Covid-19. Kegiatan ini juga perlu untuk dilanjutkan kepada tingkat yang lebih luas.

\section{PENUTUP}

\section{Simpulan}

Kegiatan pengabdian masyarakat ini memberikan pengetahuan praktis kepada masyarakat dengan cara sosialisasi dan pelatihan di Kecamatan Suko Sewu Kabupaten Bojonegoro mengenai disaster risk management upaya preventif dalam membentuk persepsi masyarakat merespons pandemi Covid-19. Dengan pelaksanaan kegiatan pengabdian masyarakat ini memberikan pemahaman dan kesadaran masyarakat yang ditunjukkan dengan peningkatan signifikan nilai pre-test dan post-test serta respons masyarakat dalam kegiatan. Dengan hasil ini dapat membantu masyarakat dalam membentuk persepsi mengenai pandemi Covid-19 dan dapat menularkan persepsi tersebut kepada masyarakat sekitar.

\section{Saran}

Kegiatan pengabdian masyarakat ini perlu dilakukan secara berkesinambungan dan perlu untuk dikembangkan lebih lanjut dalam melihat keefektivitasan kegiatan dalam menangani permasalahan yang sedang terjadi. Peran aktif berbagai pihak perlu diwujudkan dalam bentuk kegiatan untuk membentuk persepsi masyarakat dalam merespons pandemi Covid-19 kedepannya. Terakhir, pelaksanaan pelatihan tanggap bencana perlu dilakukan secara terus menerus mengingat antusiasme masyarakat desa tentang pola hidup sehat sangat tinggi. 


\section{Ucapan Terima Kasih}

Tim pengabdian masyarakat mengucapkan terima kasih atas bantuan pendanaan dari Keputusan Rektor Universitas Airlangga Nomor 523/UN3/2020 tanggal 1 Juli 2020 Tentang Pelaksanaan Program Pengabdian Kepada Masyarakat Universitas Airlangga Tahun 2020. Tim pengabdian masyarakat juga mengucapkan terima kasih kepada institusi mitra Lembaga Pemberdayaan Masyarakat Kabupaten Bojonegoro dan Pemerintah Desa Kalicilik yang terlibat dalam kegiatan pengabdian ini.

\section{DAFTAR PUSTAKA}

Barak, Y. 2006. “The Immune System And Happiness". Autoimmunity Reviews 5 (8), 523-527. https://doi.org/10.1016/j.autrev.2006.02.010

Buana, D. K. 2020. “Analisis Perilaku Masyarakat Indonesia Dalam Menghadapi Pandemi Virus Corona (Covid-19) dan Kiat Menjaga Kesejahteraan Jiwa”. Jurnal Sosial dan Budaya Syar'i 7 (3), 217-226. DOI: 10.15408/sjsbs.v7i3.15082

Hariyadi, D. 2020. "Pandemi Corona, Ribuan Orang Ikut Tabligh Akbar se-Asia di Gowa". Tempo.co, 18 Maret

Malik, D. 2020. Anies Tutup Lokasi Wisata di Jakarta, Wisatawan Pindah ke Puncak Bogor. Vivanews, 14 Maret

Mukarohmah, V. F. 2020. Panduan dan Tata Cara Menguburkan Jenazah Covid-19. Kompas, 20 Juli

Peraturan Pemerintah Nomor 21 Tahun 2020 tentang Pembatasan Sosial Berskala Besar Dalam Rangka Percepatan Penanganan Corona Virus Disease 2019

Peraturan Menteri Kesehatan Republik Indonesia Nomor 9 Tahun 2020 tentang Pedoman Pembatasan Sosial Berskala Besar Dalam Rangka Percepatan Penanganan Corona Virus Disease 2019

Keputusan Presiden Nomor 11 Tahun 2020 tentang Penetapan Kedaruratan Kesehatan Masyarakat Corona Virus Disease 2019

Keputusan Presiden Nomor 12 Tahun 2020 tentang Penetapan Bencana Non Alam Corona Virus Disease 2019 Sebagai Bencana Nasional 